\title{
SEPARATION AGREEMENT ASSET FOR INDONESIAN CITIZENS MARRIED ABROAD
}

\author{
Bella Arwinilita \\ Master of Notarial Law, Sultan Agung Islamic University \\ bellaarwinilita1995@gmail.com \\ Siti Anggraini \\ Master of Notarial Law, Sultan Agung Islamic University \\ sitianggraini727@gmail.com \\ Dwi Wisnu Wardana \\ Master of Notarial Law, Sultan Agung Islamic University \\ maswisnu72@yahoo.co.id \\ Asep Hermawan \\ Master of Notarial Law, Sultan Agung Islamic University \\ rafiannisa@gmail.com \\ Setiawan Widiyoko \\ Master of Notarial Law, Sultan Agung Islamic University \\ setiawan.wd@gmail.com
}

\begin{abstract}
Legal protection in agreements on the separation of assets in marriage between Indonesian citizens and foreign citizens as well as analyzing the authority of a notary in making an agreement on the separation of assets in marriage between Indonesian citizens. and foreign nationals. This research uses empirical normative research. The approach method used is a statutory approach, conceptual approach and case approach. Based on the research results, it can be concluded that the making of a marriage contract can provide legal protection for the party who made it. The agreement deed made in the notary can be used as written evidence in court in case of problems at a later date. Based on Article 1868 of the Civil Code and notary authority in Article 15 of the notary office law, it is stated that notaries have the authority to make authentic deeds related to all agreements. Notaries must be able to provide legal certainty in people's lives because in the deed there is evidence that clearly determines a person's rights and obligations as a legal subject in society. Notary Deed as deed which has perfect evidentiary power makes the position of Notary Deed as the first and main evidence in civil evidentiary law.
\end{abstract}

Keywords: Agreement Asset; Indonesian Citizen; Married Abroad; 


\section{A. INTRODUCTION}

As social beings, humans will need one another and socialize with each other. One form of it is to marry. This marriage will create a family that will give birth to offspring. Therefore humans in living a social life are not free from interdependence between one human being and another, this is due to the position of humans as social beings who tend to group together or make friends with other humans, so that humans are said to be as individual beings as well as individuals, social bei ngs. $^{1}$

In Article 28 B paragraph (1) of the 1945 Constitution of the Republic of Indonesia states that "everyone has the right to form a family and continue offspring through a legal marriage". Marriage is universal and is not bounded by skin color, race and nationality. It is not surprising that the number of mixed marriages continues to increase, including in Indonesia. The definition of marriage is regulated in Article 1 of Act No. 1 of 1974 concerning Marriage (hereinafter abbreviated to the Marriage Law) which applies nationally, which states: "Marriage is a physical and spiritual bond between a man and a woman as husband and wife with the aim of forming a family or household is happy and eternal based on the Supreme Lordship."2

Globalization of information, economy, transportation, cyberspace has increased human mobility by way of migration from one country to another, causing people to meet and communicate with various ethnic groups with different cultures, religions and customs. These meetings and communications allow Indonesian citizens to carry out a marriage with foreign citizens so that what is called a mixed marriage emerges. ${ }^{3}$

In fact, one of the most popular introductory processes with foreign nationals through technology is through social networks, such as via Facebook, Twitter, WhatsApp and so on which can easily connect communication between one country and another, as well as other introductory channels can be done by a couple who is married to a foreign national. $^{4}$

Mixed marriage according to Article 57 of the Marriage Law states; "What is meant by mixed marriage is a marriage between two people in Indonesia and subject to different laws due to differences in nationality and one of the parties is an Indonesian citizen." A marriage that is entered into outside Indonesia between an Indonesian citizen and a foreign citizen is legal if it is carried out according to the law in force in the country where the marriage was carried out. Meanwhile, for Indonesian citizens who do not

1 Ahlan, Suruni and Wahyono Dhamabrata, Peraturan Perkawinan di Indonesia, Diktat Kuliah, Fakultas Hukum Universitas Indonesia. Jakarta, 2019, page. 7.

2 Munasir, Rekonstruksi Hukum Perkawinan Dibawah Tangan Dalam Perspektif Fiqh Berdasarkan Nilai Kemaslahatan, Jurnal Pembaharuan Hukum, Vol II No. 1 Januari-April 2015, page.57-66

3 Herni Widanarti, Tinjauan Yuridis Akibat Perkawinan Campuran Terhadap Anak, Diponegoro Private Law Review, Vol 4 No. 1 February 2019, page.447-452

4 Irma Devita Purnamasari, Kiat-kiat Cerdas, Mudah dan Bijak Memahami Masalah Hukum Waris, Mizan Pustaka, Bandung, 2014, page.155. 
violate the provisions of the Marriage Law, as regulated in Article 56 Paragraph (1) which reads, "Marriage in Indonesia between two Indonesian citizens or an Indonesian citizen and a foreign citizen is lawful if it is carried out according to the law in force in the country where the marriage was carried out and for Indonesian citizens it does not violate the provisions of this law. ${ }^{5}$

Constitutional Court Decision No.69/PPU-XIII/2015 has loosened the meaning of a marriage agreement. With the issuance of the Constitutional Court's decision, now the agreement no longer means an agreement made before marriage (prenupical agreement) but can also be made after the marriage takes place, this is very important if an Indonesian citizen marries a foreign citizen, if he does not make a marriage agreement before the marriage takes place, there will be a mixture of assets between the two parties. Mixing of assets for mixed marriages involving immovable property such as land, if there is a break in the marriage, whether it is death, divorce and on a court ruling, the Foreign Citizen is obliged to relinquish his rights to the land within a period of 1 (one) year from the time the right is obtained as in Article 21 paragraph (3) of Law No. 5 of 1960 concerning Basic Agrarian Principles.

Based on the decision of the Constitutional Court, now the agreement it no longer means an agreement made before marriage or at the time of the marriage (prenuptial agreement) but also can be made after the marriage takes place. With thus, the decision of the Constitutional Court provides flexibility in entering into a marriage agreement. ${ }^{6}$

This provision can be excluded by the existence of a marriage agreement (separation of assets) made before the marriage takes place. Observing these conditions and legal developments regarding mixed marriages that will have an impact on joint property, therefore it is important to make an agreement to separate property in a marriage in order to provide legal certainty for both parties.

This study aims to analyze legal protection in the making of an agreement on the separation of assets in marriage between Indonesian citizens and foreign nationals and to analyze the authority of a notary on the making of an agreement on the separation of assets in marriage between Indonesian citizens and foreign citizens

\section{B. RESEARCH METHODS}

The approach method used is: Legislative Approach, Conceptual Approach and Case Approach. The specification of this research is Normative Empirical legal research. The data collection method used in this study is divided into two types, namely primary data in the form of interviews with respondents who have experienced firsthand events and secondary data or

5 J. Andy Hartanto, Hukum Harta Kekayaan Perkawinan, Yogyakarta: Laksbang Grafika, Yogyakarta, 2012, page. 1.

6 Putu Astika Yasa, Made Subawa, Analisis Putusan Mahkamah Konstitusi Nomor 69/PuuXiii/2015 Tentang Perjanjian Kawin, Journal Kertha Semaya, Vol 7 NO 12 2019, page.1-14 
library data in the form of analysis of books, literature, journals and scientific papers. The analytical method used is qualitative analysis.

\section{RESULT AND DISCUSSION}

\section{Legal Protection in the Making of Agreement on Separation of Assets in Marriage between Indonesian Citizens and Foreign Citizens}

Indonesian people realize the nature of their humanity, that is, as intelligent beings, the understanding of the values of God, religion and theology is not based on dogma, force or pressure, but is a rational understanding. Indonesian people always use their minds to the maximum in order to be able to understand the nature of God, nature, and humans. It is the result of thinking that gives birth to philosophy. ${ }^{7}$ Thus, the philosophy of jurisprudence is a part of Indonesian jurisprudence which examines truth and ultimate truth on the basis of ratio. It is this philosophical truth and justice that further drives the emergence of various ideas, concepts or ideas in the Indonesian people concerned. An Indonesian legal ideology is an ideology rooted in the value of Godhead. ${ }^{8}$

Indonesian citizens living in these communities each have a personal function and a social function. Where later we will meet someone and will have a family, meet our spouse, meet someone from any background, religion, ethnicity and can be of different countries. It is inevitable if we meet our soul mate who is a foreigner or foreigner, then falls in love and decides to get married to form a family. The problem of falling in love with a foreigner is more complex, especially when you get married later. Because it can be different religions, different languages, different cultures, different countries and different citizens. In that union, a woman who is an Indonesian citizen and a foreign citizen is married, which has been regulated in the Indonesian Law on Mixed Marriage. ${ }^{9}$

A marriage agreement is usually made for the purpose of legal protection of the assets of each husband or wife, although the law does not regulate the purpose of the marriage agreement and what can be agreed upon, everything is left to both parties. Article 1338 of the Civil Code states "An agreement or agreement made legally by the parties, shall be valid as law for the parties making it". Matters that have been agreed upon by the parties must be carried out in good faith. The agreement which has been agreed upon by the parties cannot be

7 Peni Rinda Listyawati, Indah Setyowati, Latifah Hanim, Legal Analysis of The Rejection Registration Interfaith Marriages, International Journal of Law Recontruction, Vol 4, Number 2, September 2020, page.110-123

8 Dini Amalia Fitri, Pancasila as a Legal Science Paradigm, International Journal of Law Reconstruction, Vol 3, No 2, September 2019, Page.123-133

9 Achmad Sulchan, Nurmalia Ika Widiasari, Tinjauan Yuridis Tentang Perolehan Hak Atas Tanah Bagi Perempuan Wni Yang Terikat Perkawinan Campuran, (Studi Kasus Putusan MK Nomor 69/PUU XIII/2015), Jurnal Akta Vol. 4. No. 1, Maret 2017, page.25 - 28 
withdrawn other than by the agreement of both parties or for reasons which are stated by law to be sufficient for this.

A form of government preventive legal protection against the legal consequences of marriage between Indonesian citizens and foreign nationals (Mixed Marriage) by dividing the assets made before the marriage takes place and is valid for the duration of the marriage which aims to protect the assets of the parties (prospective husbands) where the parties can determine their respective assets and/or joint assets, but the method of distribution is arranged in case of divorce.

Discussions about the issue of assets obtained in marriage by husbands and wives are still considered taboo in the eyes of the community. The general public still views this as not important. Married couples usually only question the distribution of joint assets after a divorce decision is made from the court. Even in court proceedings, there are often conflicts over the distribution of joint assets so that this condition further complicates the divorce process between them because each claims that the property is part of his or her rights. ${ }^{10}$

Marriage is actually related to the private property of the husband or wife, as well as the joint ownership rights of husband and wife during the marriage. Therefore, paragraph (1) Article 35 of the Marriage Law regulates joint assets during marriage and paragraph (2) Article 35 of the Marriage Law regulates the personal assets of each husband or wife. Strictly speaking, private property rights as human rights and collective property rights as human rights must be regulated explicitly on the extent of their scope so that there is no confusion and clash of property rights between the two. ${ }^{11}$

The result of marriage on the husband and wife's property according to the Civil Code is a round mix of assets as Article 119 of the Civil Code states that assets acquired during the marriage become joint assets including all marital assets, namely assets that existed at the time of marriage and assets obtained during the marriage. The agreement deed made before a Notary can be used as written evidence if later problems occur because the Notary Deed has perfect evidentiary power as in the category of Authentic Deed based on Article 1868 of the Civil Code.

So far, only a small proportion of Indonesians make agreements before marriage. The assumption that after marriage everything melts into one makes every couple feel reluctant to make an agreement. In fact, the prenuptial agreement does not only contain matters of property, but also the division of roles and child care.

The making of a marriage agreement is usually made by a married couple who will carry out a mixed marriage or a marriage of

10 Rahman Marwanto, Harta Gono Gini, Sengketa dan Penyelesaiannya Setelah Perceraian, Pustaka Ilmu, Jakarta, 2012, page. 56.

11 Evi Djuniarti, The Law of Joint Property Reviewed from The Perspective of Marriage Law And Civil Code, Jurnal Penelitian Hukum DE JURE, ISSN 1410-5632 Vol. 17 No. 4 Desember 2017, page. 445-461. 
different nationalities, If the married couple does not enter into a marriage agreement based on the provisions of positive legal regulations in Indonesia, then legal protection for foreigners who are married and there has been a mixture of assets as a result of marriage law in the form of land, according to the provisions of Article 21 paragraph (3) UUPA which regulates joint assets in the form of Land acquired during the marriage is not transferred for 1 (one) year, it will become state property. The provisions of Article 21 paragraph (3) of the UUPA can be exempted if there are married couples who are going to carry out mixed marriages making a marriage agreement made by a Notary Deed and/or made in writing for further registration with the marriage registrar. If an Indonesian citizen who is already married to a foreigner without a marriage agreement, you should immediately transfer land owned in Indonesia by selling or donating it to parents, children, siblings, or relatives before the government finds out which could cause the land rights to be canceled and fall to the State without compensation in accordance with Article 21 paragraph (3) of the UUPA. The issue of divorce is included in the field of personal status, where divorce between partners of the same nationality is not a problem, but it becomes a bit of a problem if the married couple have different nationalities. In addition, there are other legal consequences caused by divorce in mixed marriages between citizens, including the following:

a. The effect on joint property after marriage;

b. The consequences for child custody rights resulting from mixed marriages between citizens;

c. Impact on the nationality status of the child and each party.

The impact of mixed marriages is not only regarding the assets obtained during the marriage but also regarding the citizenship status of women who are Indonesian citizens and children who are born later. Based on Article 26 paragraph (1) of Law no. 12 of 2006 concerning Citizenship states, "Women who are Indonesian citizens who are married to men who are foreign citizens lose Indonesian citizenship if according to the law of their husband's country of origin, the wife's nationality follows the nationality of the husband as a result of the marriage." Mixed marriages can be carried out abroad or domestically if they are subject to the law in force in the country the marriage is carried out. If in Indonesia, a mixed marriage partner must comply with the prevailing laws and regulations and meet the marriage requirements as in general marriages in Indonesia. Indonesian Citizen Women who wish to retain their citizenship can submit a Statement of Intent to Remain Indonesian Citizenship to an official or representative of the Republic of Indonesia who is authorized at the residence of her foreigner husband. The statement letter is submitted by a woman who is an Indonesian citizen after three years from the date the marriage took place as regulated in Article 26 paragraph (4) of the Citizenship Law. It should be noted that 
the application may not result in an Indonesian citizen becoming a national to a dual nationality (bipatride).

The Indonesian citizen (WNI) must give up the citizenship status obtained from the mixed marriage, then he can submit a statement of wanting to remain Indonesian citizenship. Making an agreement before or after the marriage takes place, especially regarding assets depending on the wishes and agreements between the prospective husband and wife. Many have proven that the marriage agreement was made to protect women. Furthermore, mixed marriages do not differentiate between the rights of men and women in accordance with the CEDAW (Convention on the Elimination of all Forms of Discrimination Against Women) convention which emphasizes the elimination of discrimination against women and protects women's rights.

Basically, making a marriage agreement can provide preventive legal protection and repressive as the division of legal protection theory and agreement theory for the parties who make it. Preventive legal protection for the making of a marriage agreement, where the parties can determine the assets if there is a mixture of assets as a result of the law of the marriage being carried out. Furthermore, with the Constitutional Court decision No. 69/2015 can make it easier for the parties to make it after the marriage takes place as well as other agreements he makes.

\section{Notary Authority Against the Agreement Making Separation of Assets in Marriage between Indonesian Citizens and Foreign Citizens}

Based on the notary position law, it turns out that the Notary is a public official who has authority by means of attribution, because the authority is created and granted by The Notary Position Law itself. So the authority obtained by the Notary does not come from other institutions, for example from the Ministry of Law and Human Rights, even though the Decree of Appointment as Notary is issued by the Ministry of Law and Human Rights. Notary powers are also independent, autonomous as public officials appointed by the state. A Notary Public can carry out his functions at any time, without having to obtain approval from the central government. Notaries are free to carry out their functions and powers as long as they do not conflict with the laws and regulations that govern them.

In Article 15 paragraph (1) The Notary Position Law states that Notaries have the authority to make Authentic Deeds regarding all actions, agreements, and stipulations required by laws and regulations and/or those desired by those concerned to be stated in an Authentic Deed, guaranteeing the certainty of the date of making the deed, keep the deed, provide grosse, copy and excerpt of deed. All such powers as long as the deed is drawn up is not assigned or excluded to other officials or other persons stipulated by law, including the making of a 
marriage agreement for married couples who are mixed marriages, it can be made with an Authentic Deed.

It aims to provide legal certainty and legal protection for those who make it. Apart from making an Authentic Deed, in Article 15 paragraph (2) The Notary Position Law, Notaries also have the authority to:

a. Ratify the signature and set a certain date of the letter under hand by registering in a special book;

b. Submitting letters under hand by registering in a special book;

c. Make a copy of the original under hand in the form of a copy containing the description as written and described in the letter concerned;

d. Endorsing the compatibility of the photocopy with the original letter;

e. Providing legal education in connection with making deeds;

f. Making deeds related to land; or

g. Prepare a deed of auction minutes.

A written marriage agreement will result in the law losing its authenticity, considering the classification of Article 1868 of the Civil Code, which states that a deed can be said to be authentic if it fulfills the elements, namely: made in the form prescribed by law, made by or in front of authorized public officials for the purpose of making the deed and made in the authorized notary area. The difference in the making of a marriage agreement according to the Civil Code and the Marriage Law can have an impact on legal certainty for the parties making it. In Indonesia, the only authorized official to make an Authentic Deed is a Notary in which the existence of a Notary Deed in a state of law, especially Indonesia, has a crucial function.

The recognition of the Notary Deed as a deed that has perfect evidentiary power makes the position of the Notary Deed the first and foremost evidence in civil evidentiary law, so that its existence needs to be regulated in such a way so that the power of proof of the notarial deed can provide legal certainty for the party making it so that can be used as evidence in case of problems in the future. Legal certainty is a condition in which a rule is made and promulgated because it regulates clearly and logically. It is clear in the sense that there is no vagueness of norms or doubts (multiple interpretations) and it is logical in the sense that it becomes a norm system with other norms so that it does not clash or create norms conflict. ${ }^{12}$

Legal certainty refers to a clear, permanent, consistent and consistent law enforcement, the implementation of which cannot be influenced by conditions that are subjective in nature. The indicator of legal certainty in a country itself is the existence of clear legislation and

12 Peter Mahmud Marzuki, Pengantar Ilmu Hukum, Kencana Pranada Media Group, Jakarta, 2008, page. 158. 
these laws are well implemented by judges and other legal officers. ${ }^{13}$ The relevance of the legal certainty theory above with the making of a marriage agreement in Indonesia, there is a conflict of norms in which the two legal rules are overlapping. According to the author, the authority to make a marriage agreement deed in Indonesia, which is a state law, should be made by a Notary in the form of a Notary Deed in order to provide legal certainty as its authenticity is according to Article 1868 of the Civil Code. Indonesia as a rule of law must be able to provide certainty, justice and benefits to its citizens. The legal objectives that are closer to realistic are legal certainty and legal usefulness. Positivism places more emphasis on legal certainty, while functionalists prioritize legal benefits, and if it can be argued that "summum ius, summa injuria, summa lex, summa crux" which means harsh laws can injure, unless justice can help them. ${ }^{14}$

To achieve the legal objective of legal certainty in making a marriage agreement, a mixed marriage couple must make an agreement in the form of an authentic deed, not in a written form. Making a written marriage agreement, the agreement is not an Authentic Deed but an underhand agreement where the power of proof is not like an Authentic Deed made before a Notary. The power of making a Deed under hand is not the same as the power of proof of an Authentic Deed, especially in the power of proof of physical, formal, or material evidence.

The new underhanded deed has the power of proof as is the power of proof of an Authentic Deed if the acknowledgment of the parties justifying their signatures in the deed is. If the married couple makes a written marriage agreement, it is better if the agreement made is legalized or legalized by a notary as other authorities as in Article 15 paragraph (2) The Notary Position Law, namely the Notary is authorized to ratify the signature and determine the certainty of the date of the letter under hand by registering in a special book (legalization) and book a letter under hand by registering in a special book (waarmeking). Legalization is the endorsement of the letters which are made under the hand in which all parties make the letter come before the Notary, and the Notary reads and explains the contents of the letter, then the letter is dated and signed by the letters concerned are listed in a special book made by a notary. Usually this is taken if the document/letter has been signed by the parties before being conveyed to the relevant Notary Public.

The marriage agreement made under the hand is then legalized or waarmeking by a notary does not change the whole into an authentic deed, but the signature in the agreement is accepted as an under-hand deed provided that it is affixed with a thumbprint in the presence of a public official. Thus the interference of public officials is of a limited

13 Abdul Rachmad Budiono, Pengantar Ilmu Hukum, Bayumedia Publishing, Malang, 2005, page. 22.

14 Dominikus Rato, Filsafat Hukum Mencari dan Memahami Hukum, Laksbang Pressindo, Yogyakarta, 2010, page. 59. 
nature so that it does not increase the quality of the Deed under the hand to become an Authentic Deed because in its creation it does not meet the requirements in Article 1868 of the Civil Code. that a marriage agreement made before a notary must be legalized by a marriage registrar and register with the local district court. This is also regulated in Article 152 of the Civil Code which states that the agreement applies to third parties who register at the Registrar's Office of the local District Court. A marriage agreement that does not register will result in the third party, the third party will assume that the marriage uses a mixture of assets. ${ }^{15}$

However, It must be admitted that the Deed under the hand has its advantages when compared to the Deed under the hand in general where there is absolutely no interference by the official. The advantages are:

a. There is certainty about who will grow the thumbprint on the Deed (ic stamp his finger is likened to a signature).

b. There is certainty regarding the date of making the Deed. After legalization and waarmerking, the power of proof of a Deed under hand cannot be the same as an Authentic Deed.

However, when compared to an underhanded Deed that does not get legalization or waarmerking, the power of proof that has been legalized or waarmerking by a Notary official has more evidentiary power, as long as the parties acknowledge receiving the content and acknowledge the signature in the agreement.

Based on this, legalization or waarmerking that is carried out on a deed which is an underhand deed, still requires acknowledgment from the parties about the truth of the deed, even though it has been through registration or registration by a public official. In this case, the one who can qualify the power of proof of the Deed under the legalized hand or waarmerking is the judge. Seeing the importance of making a marriage agreement for married couples in mixed marriages because there are several things that are commonly agreed upon, including:

a. Assets inherited into a marriage, whether assets obtained from individual businesses or from gifts, inheritance and so on;

b. All debts carried by the husband and wife in the marriage will be borne by each;

c. The wife will take care of her personal assets, both movable and immovable;

d. To take care of his property, the wife does not need the consent of husband, and vice versa;

15 Muhammad Akbar Aulia Ramadhan, KN. Sofyan Hasan, Achmad Syarifudin, Perjanjian Perkawinan Terhadap Harta Yang Diperoleh Selama Perkawinan Pasca Perceraian, Repertorium: Jurnal IImiah Hukum Kenotariatan, Vol. 6 No. 2 November 2017, page.157169 
e. The husband's economic responsibility is to provide a living for his wife and children.

If you look at the provisions above, the position of the marriage agreement is very necessary because there will be a mixture of assets as a result of the marriage in the absence of a marriage agreement that is made. The concept of a marriage agreement in principle is inseparable from the concept of joint assets in marriage which makes it easier to determine the quantity of the assets of each married partner.

Thus, the existence of a marriage agreement certainly cannot erase the rights of a couple as heirs. The only difference is determining what is included in the inheritance and which is not. This causes that a person becomes an heir for two reasons, namely (1) because of the law that determines being an heir; (2) because of the testament or appointed by the heir. The existence of a marriage agreement does not result in a person losing his/her right as an heir, except because of the law that invalidates a person's right to become an heir. The marriage agreement only regulates how the husband and wife's assets are treated in the marriage.

What becomes an inheritance is the net assets of a person who has died after being separated from joint assets (if any) and deducting all obligations to third parties, therefore it is important to distinguish between inheritance and inheritance assets. It can be concluded that the Notary's authority as referred to in Article 15 of the the notary position law, the Notary is authorized to make an Authentic Deed regarding all actions, agreements, and stipulations required by statutory regulations and/or desired by those concerned to be stated in the Authentic Deed, including making marriage agreements for married couples. Mixed marriages can then be made with an Authentic Deed, to guarantee legal certainty and legal protection for the party making them. In the theory of legal protection itself, it contains protection from the government for its citizens, guarantees of legal certainty, relating to the rights of citizens and the existence of penal sanctions for those who violate them. In addition, notaries should be careful and read carefully when receiving a marriage agreement deed, given the many types of marriage agreements.

There are many possible substances stipulated in the marriage agreement. It may be that what is separated according to the marriage agreement is only assets and does not include joint assets. Each type of marriage agreement has different legal implications

\section{CONCLUSION}

The making of a marriage agreement can provide legal protection for the parties who make it. In addition, if at any time a conflict arises between the parties who have entered into a mixed marriage, the marriage agreement that has been made before the marriage takes place can be used as a reference and basis for each party to carry out their obligations, and to 
provide boundaries of rights and obligations between them. The agreement deed made in a notary can be used as written evidence if in the future there is a legal problem between the husband and wife who enter into a marriage agreement before a notary. This is because the Notary Deed has perfect evidentiary power as is the category of authentic deeds based on article 1868 of the Civil Code and the authority of the Notary in Article 15 The Notary Position Law

\section{BIBLIOGRAPHY}

\section{Book:}

Abdul Rachmad Budiono, 2005, Pengantar Ilmu Hukum, Bayumedia Publishing, Malang;

Ahlan, Suruni and Wahyono Dhamabrata, 2019, Peraturan Perkawinan di Indonesia, Diktat Kuliah, Fakultas Hukum Universitas Indonesia. Jakarta;

Dominikus Rato, 2010, Filsafat Hukum Mencari dan Memahami Hukum, Laksbang Pressindo, Yogyakarta;

Irma Devita Purnamasari, 2014, Kiat-kiat Cerdas, Mudah dan Bijak Memahami Masalah Hukum Waris, Mizan Pustaka, Bandung, 2014

J. Andy Hartanto, 2012, Hukum Harta Kekayaan Perkawinan, Yogyakarta: Laksbang Grafika, Yogyakarta;

Peter Mahmud Marzuki, 2008, Pengantar I/mu Hukum, Kencana Pranada Media Group, Jakarta;

Rahman Marwanto, 2012, Harta Gono Gini, Sengketa dan Penyelesaiannya Setelah Perceraian, Pustaka Ilmu, Jakarta;

\section{Journal:}

Achmad Sulchan, Nurmalia Ika Widiasari, Tinjauan Yuridis Tentang Perolehan Hak Atas Tanah Bagi Perempuan Wni Yang Terikat Perkawinan Campuran, (Studi Kasus Putusan MK Nomor 69/PUU XIII/2015), Jurnal Akta Vol. 4. No. 1, Maret 2017;

Dini Amalia Fitri, Pancasila as a Legal Science Paradigm, International Journal of Law Reconstruction, Vol 3, No 2, September 2019;

Evi Djuniarti, The Law of Joint Property Reviewed from The Perspective of Marriage Law And Civil Code, Jurnal Penelitian Hukum DE JURE, ISSN 1410-5632 Vol. 17 No. 4 Desember 2017;

Herni Widanarti, Tinjauan Yuridis Akibat Perkawinan Campuran Terhadap Anak, Diponegoro Private Law Review, Vol 4 No. 1 February 2019; 
Muhammad Akbar Aulia Ramadhan, KN. Sofyan Hasan, Achmad Syarifudin, Perjanjian Perkawinan Terhadap Harta Yang Diperoleh Selama Perkawinan Pasca Perceraian, Repertorium: Jurnal Ilmiah Hukum Kenotariatan, Vol. 6 No. 2 November 2017;

Munasir, Rekonstruksi Hukum Perkawinan Dibawah Tangan Dalam Perspektif Fiqh Berdasarkan Nilai Kemaslahatan, Jurnal Pembaharuan Hukum, Vol II No. 1 Januari-April 2015;

Peni Rinda Listyawati, Indah Setyowati, Latifah Hanim, Legal Analysis of The Rejection Registration Interfaith Marriages, International Journal of Law Recontruction, Vol 4, Number 2, September 2020;

Putu Astika Yasa, Made Subawa, Analisis Putusan Mahkamah Konstitusi Nomor 69/Puu-Xiii/2015 Tentang Perjanjian Kawin, Journal Kertha Semaya, Vol 7 NO 12 2019; 